\title{
INTERACTIVE LEARNING MATERIALS FOR SUBJECTS MUSIC THEORY AND SOLFEGGIO IN THE SLOVENIAN PRIMARY MUSIC SCHOOL
}

\author{
Katarina Zadnik \\ Academy of Music, University of Ljubljana, Slovenia \\ katarina.zadnik@ag.uni-lj.si
}

\begin{abstract}
With the outbreak of the pandemic, general and music education shifted completely to remote learning as the only possible form. The research looks into didactic approaches using digital technology adopted by active teachers and students in the Slovenian music school in asynchronous distance learning. On a sample of 9 active teachers and 16 students, the research study examined 31 interactive learning materials in order to identify innovative didactic approaches using digital tools which were applied to achieve learning objectives within musical activities of the Music Theory and Solfeggio. Based on qualitative-quantitative approach, the research showed a low presence of didactic approaches using digital tools. Even though the results show a higher level of use of digital technology among students, the research focused much more on the presence of e-learning materials as well as predominantly traditional teaching approaches, similar to the classical type of classroom teaching.
\end{abstract}

Keywords: asynchronous distance learning, didactic approaches using digital tools, i-learning materials, music school, Music Theory, Solfeggio

\section{Introduction}

Digital technology which is integrated in all areas of our lives is also an integral part of education. More than a decade ago, the Key Competences for Lifelong Learning $(2007,3)$ was launched, which identified digital competences as one of the eight crucial competences 
in everyday life. The versatile presence and growing trend of the use of digital technologies which began to change the traditional ways of human communication and operation promoted the emergence of the document European Framework of Digital Competences for Educators: DigCompEdu in 2017 (Redecker, 2017). Due to the identified gap between the use of digital technologies for personal purposes and learning/teaching purposes (Jedrinović et al., 2019, 35), the DigCompEdu document $(2017,9)$ defines specific digital competences related to professional and pedagogical competences for teachers. Intended for all educators and learners, the document defines the developmental levels of digital competences, it is the starting point for identifying training needs and exploiting the potential of digital technologies to improve teaching and learning. The document also envisages the development of digital competences by students. The teacher's role in the contemporary education is not only to promote specific knowledge in individual academic areas, but also to accustom students to an appropriate and safe use of digital technologies as well as to support and empower them in the development of digital competences as transversal competences.

Recently, digital technology was included in the Slovenian educational sphere as a tool 1) in traditional forms of teaching, 2) in synchronous or asynchronous distance learning using e-materials, and 3) in a combination of the two previously mentioned forms (Gerlič, 2013, 74). With the outbreak of the pandemic, general and music education has switched completely to remote learning as the only possible form of teaching and learning. Thus, for the first time, the complete transition to distance learning fully required a direct use of information-communications technology (further on: ICT) in a learning process as well as adequately developed digital competences by teachers and students. The situation has triggered studies of the effectiveness of distance learning in many European countries. The research, conducted among primary and secondary school teachers in all Slovenian regions, confirmed a higher level of stress experienced by teachers in case of remote teaching as well as a higher level of competences in teachers, who were previously trained in using digital technology in relation to teaching and learning processes (Kranjc et al., 2020, 180).

Due to the pandemic outbreak, the new situation has forced all those involved in the educational settings to use digital technologies for 
teaching and learning in remote forms. Thus, new and innovative didactic approaches using ICT and flexible forms of teaching and learning in virtual environments have begun to be established. Didactic approaches using ICT are diverse and often related to the characteristics and needs of educational areas as well as the developmental periods (Jedrinović et al., 2019, 33, 41-46). For a meaningful selection of digital technologies which will support effectively teaching and learning as well as the achievement of learning objectives teachers need certain skills. The transfer of teachers' digital skills and knowledge into a learning process also has a reciprocal effect on the development of the previously mentioned competences by the participants in the learning process (Luštek et al., 2019, 54, 67). Drožđek et al. $(2019,11,12)$ emphasize the importance of appropriate choice of digital tools in creating and designing interactive learning materials (i-learning materials), and point out the teacher's knowledge and understanding of cognitive, psychological effects of these materials by students as well as technical difficulties in using them (Rossing et al., 2012, 3; Kolman and Rugelj, 2019, 98).

The authors stress the importance of creating i-learning materials, especially from the motivational point of view, which will encourage learning and active involvement of ICT in the learning process. Domestic (Drožđek et al., 2019, 11, 14) and foreign authors (Swig, 2015; Gonzalo, 2011 in Drožđek et al., 2019, 14) indicate that one of the biggest obstacles to the effective integration of digital technology into the learning process is inadequate training for meaningful use of ICT for educational purposes. The results of the European survey in the integration of ICT for educational purposes, conducted within the framework of MENTEP (Mentoring Technology Enhanced Pedagogy) in 2017/18, showed that Slovenian schools are adequately equipped with digital technology compared to other European Union countries. Despite this fact, the rare use of computers by students in the learning process as well as the constant decline of digital competences by the Slovenian teachers compared to other countries in Europe are noticeable (Flogie and Aberšek, 2019, 14, 15). The results of the pilot study on a sample of 56 higher education teachers, from the University of Ljubljana also showed that teachers expressed the greatest desire for training in creating and designing i-learning materials, appropriate use of digital envi- 
ronments (LMS environments) and ICT tools for formative assessment (Drožđek et al., 2019, 19-23).

Quality and efficient transfer of appropriate use of ICT resources and activities in the study process has positive effects on the development of digital competencies by students. The results of the pilot study (Drožđek et al., 2019, 23-26) carried out on a sample of 163 students of pedagogical program studies at the University of Ljubljana, showed that $69 \%$ of students understood the learning contents better, $73 \%$ students assessed positively the ICT-supported activities in relation to the discussed learning content, and as much as $93 \%$ of students expressed that they transferred the digital skills acquired during lectures and exercises into their teaching practice. The described results show the extraordinary importance of the appropriate integration of digital technologies in the study process by future teachers, based on examples of good practice, to enable the acquisition of digital competences and their subsequent direct transfer into the teaching praxis and later pedagogical profession (Luštek et al., 2019, 68). Studying a sample of 1,500 students of the University of Ljubljana, Urbančič et al. (2019, 78-79) found out that, compared to students of other study areas, students of artistic study areas evaluated their own digital competences in organizing, planning and implementing the learning process the lowest and expressed their beliefs that the use of digital technology does not necessarily diversify the learning process. We assume that students' standpoints stem from the belief that the arts are creative activities in themselves. Music lessons, which reflect the basic activities of music (Oblak, 1997, 121), also create opportunities for an active and student-centered learning process.

Future music teachers gain digital competences within the special didactics and pedagogical practices, subjects where they acquire basic pedagogical and didactic competences, but digital education simultaneously runs scattered around and integrated in other subjects areas as well (Urbančič et al., 2019, 73). A pilot qualitative study on a sample of ten students of the department of Music Education at the Academy of Music in Ljubljana from 2017/18 showed that students had a better understanding of the learning content, when using ICT tools. They also evaluated positively the activities supported by digital technology. In the frame of teaching practices, they assessed positively the use of ICT tools in writing teaching preparations, faster access to data and expansion of the 
discussed learning contents with ICT. As a disadvantage, they pointed out the loss of data due to inadequate storage, thwarted access to online resources, and excessive use of digital technology. Regarding the learning process, they stressed the danger of loss of active learning forms associated with basic music activities. The results of the study also showed that students choose the appropriate ICT tools and activities according to the technological capabilities of learning environments, and it was also found that students focused more on the digital technology and less on innovative didactic approaches to learning and teaching supported by ICT (Rotar Pance and Bohak Adam, 2019, 275).

Digital technology has become an integral part of the Slovenian music-school education, and represents an important support and didactic tool for teachers and pupils in music education. A study carried out in 2016 which examined the use of ICT in music-school education (Valant, 2016, 233) on a sample of 110 teachers showed that teachers mostly used digital technology in blended forms of teaching and learning to listen to recordings (93.3\%), use metronome applications $(51.4 \%)$, and record music performing within the learning process (49.5\%). Kolman (Kolman and Rugelj, 2019, 84, 85) who studies classical forms of strings instrumental teaching supported by digital technology, emphasizes the importance of blended forms of violin and viola teaching, since those forms offer new dimensions by using ICT resources and activities. He explains the advantages of blended forms of learning with the Meyer's theory of multimedia learning, which is based on different perceptual learning styles. In line with that theory, he uses the Matc My Sound (MMS) programme as a digital tool for assessing the intonation correctness of scale-playing performance.

Until recently, digital technology has been an important support in traditional forms of teaching and learning. The full transition to distance learning and teaching, after the first pandemic outbreak, launched the use of ICT as the only possible form of implementation of the learning process at individual instrumental lessons and Music Theory and Solfeggio group lessons. Distance learning can be implemented synchronously (simultaneously) via live videoconference, or asynchronously via printed or recorded instructions, audio and video displays, video lectures, transmitted programmes and applications for monitoring the accuracy of intonation and rhythmical performance, piano/mu- 
sic matrices for singing accompaniment, hyperlinks to online resources and music libraries, as well as virtual portals for teacher-student, student-student interaction (Deverich, 2012, 16, 17). The results of a study, conducted after the first pandemic outbreak, on a sample of 238 instrumental teachers from all Slovenian regions showed that teachers mostly taught in the form of synchronous distance learning in combination with the use of videos/audio recordings, e-communication, and the least through telephone conversations (Šimunovič, 2020, 30).

Since the above mentioned study was conducted among teachers of individual instrumental areas, the question of distance learning forms arises regarding the group subjects Music Theory and Solfeggio. Unlike instrumental lessons, which predominantly support individual learning forms, Music Theory and Solfeggio emphasize collaboration in group music making, within which, consequently, social interactions and development of social skills are initiated. Both subjects are independent, compulsory and equivalent to individual instrumental areas. With their specific characteristics and musical activities, they promote holistic (musical) development, and establish a bridge toward musical art and culture. Achievement of learning objectives takes place within the five basic activities: solfeggio, performing and interpretation of examples from the music literature, listening, creating, music-theoretical and formal knowledge. These activities, that reflect the core areas of music, encourage the active role of pupils and support pupil-centered education. After the first outbreak of the pandemic, the traditional approaches were replaced by didactic approaches using ICT tools and virtual learning environments at both subjects. Teaching practice showed that teachers of both group subjects initially conducted asynchronous forms of distance learning, a type of learning in which the student and teacher do not communicate directly in real-time, with the support of interactive learning materials. Interactive learning materials or interactive multimedia learning materials - hereinafter we will use the term 'i-learning materials' - are considered as online learning worksheets (Gerlič, 2006, 34; Ampa, 2015, 56), interactive videos, presentations and animations (Drožđek et al., 2019, 18).

The main goal of our research was to discover how and with which digital tools did active teachers and students achieve learning objectives with i-learning materials in asynchronous forms of distance learning. 
On this basis, we comparatively determined the presence of innovative didactic approaches with the support of ICT as well as evaluated the competence of students and active teachers in the appropriate use of digital technologies at group subjects Music Theory and Solfeggio in primary music school. To that purpose, the following research questions were set:

1. What formats of i-learning materials were used in asynchronous distance learning forms by active teachers and students at the subjects Music Theory and Solfeggio?

2. Which ICT tools did active teachers and students use to achieve learning objectives?

3. Were there any differences in the innovative didactic approaches using ICT tools among active teachers and students?

\section{Methods}

\section{Research sample and description of the research}

The research sample included 16 students of the second-cycle master's study programme Music Education at the Academy of Music, University of Ljubljana, and 9 active teachers of Music Theory and Solfeggio in the Slovenian primary music school. On basis of the qualitative approach, we reviewed and analyzed 31 i-learning materials, of which 16 materials by students and 15 materials by active teachers.

During a three months-period of the first pandemic outbreak - from March to May 2020 - active teachers and students prepared i-learning materials for asynchronous distance learning. Teachers' i-learning materials were obtained in the open access website Sodelov@Inica Music, which was designed by the National Education Institute of the Republic of Slovenia for the purpose of publishing and exchanging i-learning materials among teachers of Music Theory and Solfeggio. I-learning materials of students were obtained in the Didactic Laboratory (DIDlab GP), a virtual classroom, which was designed for the purpose of conducting teaching practice at the Department of Music Education, Academy of Music in Ljubljana. Using the content analysis method of data collection, we analyzed 16 i-learning materials of students and 15 teachers' i-learning materials. 


\section{Research instruments, data collection and analysis}

Data collection was held from October to November 2020. Based on the content analysis method of data collection, three coding categories were formed representing salient thematic sets: 1) formats of the designed i-learning materials, 2) the use of ICT tools (resources and activities), and 3) the involvement of music activities in i-learning materials. The obtained data by individual categories were numerically processed and the results are presented as frequencies and frequency distributions ( $\mathrm{f} \%$ ).

Research was conducted with a combined qualitative and quantitative approach. Qualitative approach was used for analyzing i-learning materials of active teachers and students. Using the content analysis method of data collection, we analyzed and evaluated the formats of i-learning materials, and the use of ICT tools to achieve learning objectives in the activity areas of both subjects. The obtained qualitative results were supported by descriptive statistics of frequencies and frequency distributions (f, f\%), represented in tables and graphs.

\section{Results}

\section{I-learning materials'formats}

Graph 1 shows that teachers and students most frequently used a Word Document $(67 \%)$ as the basic format for the production of $i$ learning materials, and to a lesser extent a PDF document (19\%) and a PPT presentation (14\%). Word Document was used in $80 \%$ by teachers and in $50 \%$ by students, PDF format was used in $6 \%$ by teachers and $31 \%$ by students, and PPT format was used in $13 \%$ by teachers and $18 \%$ by students. These were the primary source documents in which teachers and students gave instructions and assignments for pupils as well as wrote their own explanations of new subject matter. These formats were also the starting point for directing pupils to further use ICT resources and activities in order to achieve the learning objectives set. The analysis of i-learning materials showed that teachers and students did not use animations or video materials as the basic starting formats in the implementation of asynchronous distance learning. 
Graph 1. Formats of the i-learning materials created by teachers and students

\section{Formats of i-learning materials}

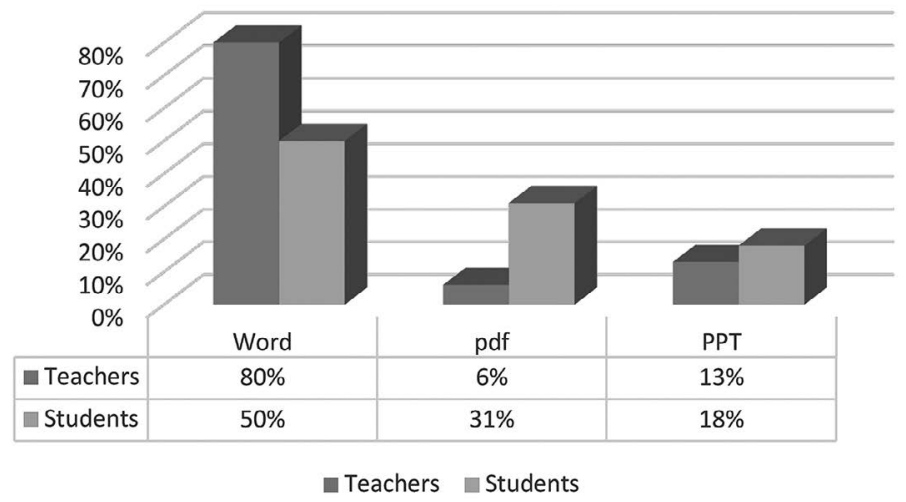

Since Music Theory and Solfeggio include five basic musical activities to encourage the development of musical abilities, skills and knowledge, one of the research question aimed at examining what musical activities teachers and students included in i-learning materials to achieve the learning objectives of both subjects.

Graph 2. Music activities included by teachers and students

Music activities in i-materials

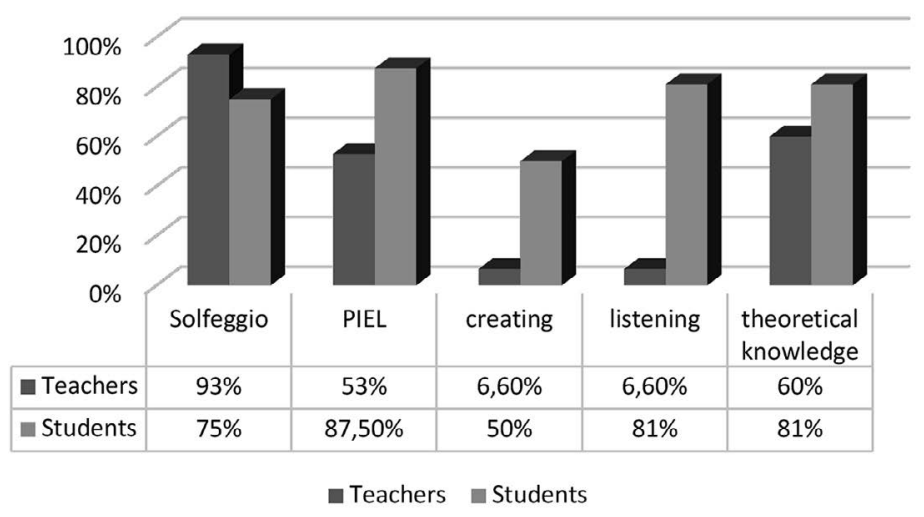


In line with the Slovene music-didactic doctrine, teachers and students included various music activities envisaged by the curricula for the subjects Music Theory and Solfeggio. Graph 2 shows that, compared to teachers, students included all the planned activities in a more balanced way. The solfeggio activity, which is related to auditory perception and performance of musical examples and represents a cornerstone in the development of musical abilities, skills and knowledge, is associated to the activity performing and interpretation of examples from music literature (PIEL). In the latter activity, pupils deepen the preliminary training of the rhythmical, melodic and harmonic abilities as well as the ability of aesthetically performing (Zadnik, 2019, 106). The comparison of the included activities among teachers and students showed (Graph 2) that teachers mostly implemented the solfeggio activity (93\%), while students dedicated more attention to the activity performing and interpretation of examples from music literature (PIEL, $87.5 \%$ ). The obtained results were related to the fact that teachers used textbooks consistently, while students were encouraged to independently select the learning topics and consequently to independently select the music contents as well as activities and tasks for pupils. The content analysis of the teachers' i-learning materials showed that they mainly used the prepared worksheets to direct their pupils to the use of standard textbooks. It was also observable that in the cases of listening to music they directed them mostly to use the YouTube channel. The comparison of results also showed that students more likely included activities listening (81\%) and creating (50\%) than teachers (6.6\%). Students also planned a slightly higher share of learning objectives in the area of music-theoretical and formal knowledge (81\%). We assume that the result can be associated to the students' one-time preparation of ilearning materials in the frame of their teaching practice. On the other hand, the result of the teachers' planning of learning objectives in this area $(60 \%)$ probably indicates the consideration of the pupils' processdevelopmental aspect and thus the gradual achievement of the learning objectives over a longer period.

The results are alarming for the activities creating and listening, since teachers included these activities in an extremely low proportion $(6.6 \%)$. From this, the question arises, what are the barriers in conducting musical creativity and listening to music, and which reasons prevent 
the implementation of these activities in the learning process, without or with the support of ICT tools. In further analysis, we were interested in which ICT tools were used by teachers and students to achieve the planned learning objectives in individual activities.

\section{The ICT tools used in achieving learning objectives}

Graph 3. The use of audio and video recordings

\section{The use of audio/video recordings}

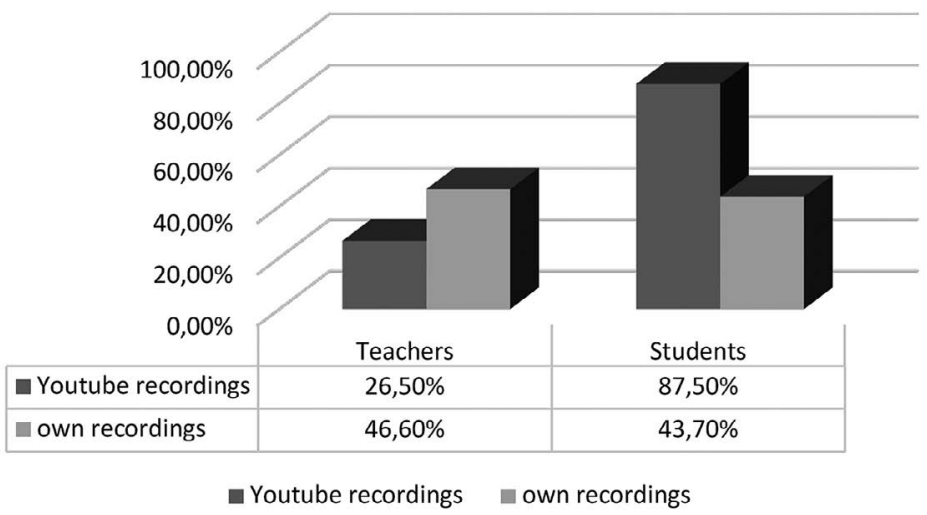

Graph 3 shows that teachers and students prepared and included audio and video recordings for the planned activities, which appeared within the initial formats of the prepared i-learning materials. Students (87.5\%) used the already posted video recordings on the YouTube channel more frequently than teachers $(26.5 \%)$, as well they prepared their own recordings and publish them online in a slightly higher proportion (43.7\%) compared to teachers $(46.6 \%)$. Content analysis showed that teachers only prepared their own audio recordings of rhythmical and melodic exercises as well as music dictations, while students also prepared video recordings. Teachers posted their own audio recordings on the YouTube channel or the Google Drive storage, while students also posted them as part of PPT presentations and within the intended online classrooms. Video recordings created by students included demonstration of body relaxation exercises, breathing and singing exercises, learn- 
ing rhythmical contents in a way of body percussion. Students' audio recordings were mainly related to the demonstration of music contents to pupils, the imitation method, (musical) piano matrices for at-home singing, training of the auditory perceptions (intervals, cords, scales) and identification of musical elements in the activity of solfeggio.

The comparison of the analyzed audio and video recordings showed that students gave pupils clear and concrete written instructions about how to use the recordings, while some teachers $(33.3 \%)$ did not give any particular instructions. We noticed that in such cases teachers omitted the systematical didactic procedures in the area of rhythmical and melodic exercises, so the examples were performed according to the method of synchronous singing (along with the teacher), and not according to the standard procedures of the method of working with notation. With both, teachers and students, we occasionally missed a larger exploiting of recordings. The audio and video recordings indicated the possibility of upgrading i-learning materials with the partial or full inclusion of video lectures. Video lectures are an appropriate support in distance learning approaches, namely, in the sense of addressing pupils in the context of new subject matter. The results show that only one student planned to conduct a lesson in the synchronous form of distance learning via videoconference (Zoom) with prior flipped learning approach.

Graph 4. ICT tools used in the planned activities among teachers and students

ICT tools used in activities

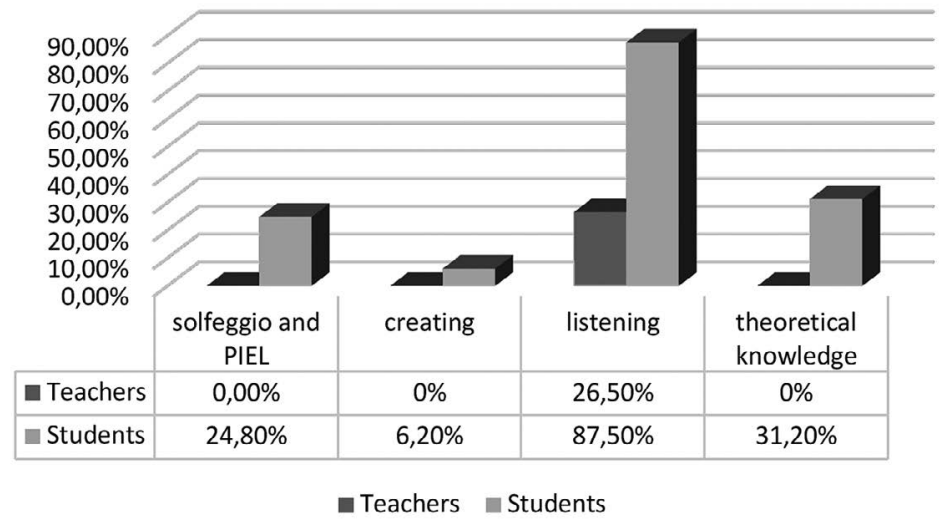


Graph 4 shows that teachers used ICT tools to achieve learning objectives only in the activity listening to music (26.5\%), while students directed pupils to use ICT tools in other musical activities as well. With the content analysis method of data collection, we found out that students chose diverse ICT tools according to the musical activities planned. Metronomeonline.com was used in $6.2 \%$ for training steady metric pulse and the accuracy of rhythmical contents; the application SightReading Mastery was used in $6.2 \%$ for checking the accuracy of music performing/singing; Musictheory.net was utilised in $6.2 \%$ for training the auditory-analytical perceptions in the harmonic area (intervals, chords); the application $H 5 P$ was utilised in $6.2 \%$ for training the auditory-analytical detection of the different modes. Students used the MuseScore application in $6.2 \%$ to encourage improvisation of the rhythmical and melodic contents at the activity creating. For consolidating the music-theoretical knowledge and definitions, the Slovenian application Glossary of Music Theory was utilised in $12.5 \%$ along with the application $H 5 P$, in $6.2 \%$, and application Kahoot, in $12.5 \%$. In the majority of cases, the previously mentioned web applications were openly available, and since most of these were in the English language, students prepared the instructions for the pupils in the Slovenian language.

The differences among teachers and students in using ICT tools stem from the fact - as indicated by the content analysis of i-learning materials - that $86 \%$ of teachers, within the previously presented basic formats, directed their pupils to the use of textbooks, while only $19 \%$ of students included the use of textbooks in i-learning materials. We assume that teachers' focus on the textbook use led to the lower utilization of ICT resources and activities in achieving learning objectives. Beside that, the results pointed out that both, teachers $(40 \%)$ and students (37.5\%), planned homework for pupils, with which they obtained feedback about each individual's musical progress. Compared to teachers (6.6\%), students $(37.5 \%)$ focused more often on preparing homeworks with the support of digital technology, namely, recordings of pupils' musical performances. The obtained results indicate the tendency of formative assessment of pupils' musical development by teachers and students (Kavčič Pucihar, 2019, 130). With regard to that result, the question whether pupils have developed digital skills to perform tasks with ICT support was raised. 


\section{Innovative didactic approaches using ICT tools by teachers and students}

By analyzing the content of i-learning materials, we discovered that teachers and students planned to achieve learning objectives in all five basic activities of the subjects Music Theory and Solfeggio. The comparison of the quantitative results showed (Graph 2) that students included all five activities in a much more balanced way than teachers. The obtained results show that teachers included activities listening (6.6\%) and creating (6.6\%) in the lowest proportion. Even though the results indicate that students included both activities (creating in 50\%, listening in $81 \%$ ) in a higher proportion than teachers, we have to stress that the share of the creating activity was the lowest also among students. The obtained results suggest that teachers and students follow the principles of the Slovenian music didactics, however, teachers mainly dedicate their attention to the solfeggio activity in the learning process. Solfeggio is a fundamental starting point activity in the acquisition of musical images in the rhythmical, melodic and harmonic areas, and is a key factor for understanding of musical theoretical concepts and definitions (Zadnik, 2019, 101). As regards the lowest results in achieving the learning objectives at the creating activity, we can assume that there is still a high presence of the prevailing concept of using the method of working with notation as a key starting point in the acquisition of musical abilities, skills and knowledge (Zadnik, 2019, 126,127).

The results (Graph 4) also reveal a lower use of ICT tools in achieving learning objectives in the individual activities. We noticed a slightly higher use of ICT in the listening activity, while these tools were used less in other activities (by students) or were not used at all (by teachers). We found that both teachers (46.6\%) and students (43.7\%) prepared their own audio or video recordings to achieve the planned learning objectives in the activities solfeggio and performing and interpretation of examples from the music literature. By reviewing and analyzing the recordings' contents, we concluded that such recordings could be an excellent starting point for guiding and directing pupils in the case of asynchronous distance learning. The analysis also showed that recordings have a great potential in introducing and explaining new learning contents. They could be used to address pupils as well as communicate instructions and demonstrate various music presentations for pupils. 
Recordings create a feeling of direct contact in a teacher-pupil relation, which creates, especially in the youngest pupils, a feeling of a direct social connection and consequently a higher motivation for schoolwork.

\section{Discussion}

The comparison between teachers and students in their use of didactic approaches including ICT tools to achieve learning objectives showed that students included such approaches in a higher proportion, while teachers mostly followed the traditional teaching approaches by using the regular textbooks. We assume that teachers directed their pupils in ustilising the textbooks due to the fact that the textbook is a key learning material for the pupil (Winkler Kuret, 2006, 13). It encompasses key information related to musical concepts and definitions, as well as musical contents and activities supporting the development of the fundamental musical abilities, skills and knowledge. The differences between the use of innovative, ICT supported didactic approaches between teachers and students stem mainly from the fact that students were encouraged to prepare i-learning materials for their preferred learning units in relation to the learning objectives in the curricula of both subjects. Students were stimulated to use a wide range of ICT recourses, activities and tools in achieving planned learning objectives, beside or separately from the regular Music Theory and Solfeggio textbooks. Even though the results show a higher level of use of digital technology among students, we have to stress that in both groups traditional teaching approaches prevailed, similarly as in the classical type of classroom teaching.

In distance learning and teaching, didactic competences related to the knowledge and appropriate use of digital technology for achieving learning objectives are emphasised. The forms of using digital technology in asynchronous distance learning differ from the use of ICT tools in classical teaching in the classroom. With these forms of teaching and learning there are needs for 1) pupils' empowerment for an effective use of digital technology in the learning process, 2) the promotion of the active learning forms by the pupil-centered approach, and 3) the consideration of the individualization and differentiation didactic principles in supporting a greater learning personalization (Flogie and Aberšek, 
$2019,19)$. The research revealed that teachers and students particularly promoted individual learning forms, while individualized tasks to support different pupils' needs in way of providing principle personalization, were not present. Thus, the constructivist learning approach, based on one's own experience, (Savage, 2007, 73), as well as collaborative learning approach (Rossing et al., 2012, 3) that would support the holistic development of musical abilities, skills, and knowledge, were omitted. In an experimental study of 10- to 11-years-old pupils in primary school, Lango $(2011,137,139,140,154)$ identified positive effects of using ICT in the learning process on the pupils' motivation and progress in the development of rhythmical and melodic pitch. The above mentioned findings raise the following questions in relation to the present research 1) how did the created i-learning materials address and motivate pupils for learning, and 2) were pupils able to use ICT tools to fulfil the planned tasks and activities, since Lango $(2011,164,181)$ confirmed the lack of proper ICT use by pupils and different levels of their digital and music literacy.

The fundamental aim of music education in the primary music school is that pupils gradually acquire basic music-theoretical and formal knowledge as well as develop the ability of functional musical literacy. Musical literacy, which encompasses the development of musical images, in the form of inner hearing, as well as knowledge, in the sense of understanding musical concepts and definitions, develops from musical experiences to a gradual acquisition of musical abilities, skills and knowledge. Since music is an auditory art, learning music should be supported by various perceptual learning styles, such as auditory, visual, and motor (kinesthetic) learning styles (Tomić, 2003, 72, 73). According to the Mayer's theory $(2013,170)$, which largely confirmed the cognitive model of learning by multimedia, the question arises in relation to the present research, if and how i-learning materials supported different learning modalities by pupils in asynchronous form of distance learning. The analysis of i-learning materials confirmed that both teachers and students promoted all learning modalities, even though the question regarding pupils' response to the planned activities, by which teachers promoted active kinesthetic forms of learning as key form of musical learning, remains open. The research results, carried out by instrumental teachers in the primary music school, showed (Šimunovič, 
2020,33) that teachers reported shortcomings brought about of distance learning, especially in the areas of group music making, musical performances, body posture, intonation, interpretation and quality of sound as well as technical performance. The acquired research results require further studies to answer the open questions of distance learning at $\mathrm{Mu}-$ sic Theory and Solfeggio.

\section{Conclusion}

The content analysis of didactic approaches, examined through the instructions and tasks for pupils, showed predominantly traditional teaching approaches, while the presence of innovative didactic approaches using ICT was low. With the content analysis, learning materials could be mainly classified in the category of e-materials. The findings show that both teachers and students focused on digital technology, and less so on the didactic approaches using ICT (Rotar Pance and Bohak Adam, 2019; Norman, 1993, in Mayer, 2013, 166), with which the pupils' needs and pupil-centered approach would be considered. The pupil-centered approach with the appropriate use of ICT could encourage the development of metacognitive learning and self-regulatory learning as key factors in the development of musical abilities, skills and knowledge (Kavčič Pucihar, 2019, 105, 111). On the contrary, Šimunovič $(2020,33)$ found that the transition to distance learning by individual instrumental teaching supported new teaching strategies, increasing self-regulation of learning in terms of independence, selfcontrol, self-criticism and self-awareness by pupils. These results are crucial for further directions in training of active teachers and students in the area of digital competences and their appropriate use in learning and teaching processes at the Music theory and Solfeggio group subjects. Teachers' knowledge about the adequate digital technology and its appropriate use in relation to the didactic approaches, supported by the principles of systematization and continuity in the asynchronous learning, will contribute to effective forms of music learning. The research, conducted after the first wave of pandemic outbreak, reveals the needs for specific training for teachers and students which would acquaint them with the specific ICT tools for the realization and qualitative implementation of musical activities. The research results are an 
important starting point for further reflections about concrete solutions in the area of digital literacy development in terms of adequate training of teachers as well as educational settings of students. Due to the small research sample and the particular period of collecting data (the first three months after the outbreak of the pandemic), the present research also has its limitations. The obtained results could not be generalized to the entire population of the Slovenian teachers and students. Thus, there is a need for further studying of the active teachers' and students' specific needs regarding the discussed topic, as well as to identify the effects of distance learning on pupils' learning outcomes.

\section{References}

Akademija za glasbo, Univerza v Ljubljani (2020), Didaktični laboratorij Glasbena pedagogika. Available at: https://ucilnice.arnes.si/course/view. php?id=29167 [20 July 2021]

Ampa, Andi Tenri (2015), "The Implementation of Interactive Multimedia Learning Materials in Teaching Listening Skills", English Language Teaching, 8(12), pp. 56-62. Available at: https://files.eric.ed.gov/fulltext/EJ1084334. pdf [27 April 2021] https://doi.org/10.5539/elt.v8n12p56

Deverich, Robin Kay (2012), "Distance learning for strings", https://violinonline. $\mathrm{com} /$. Available at: https://www.violaonline.com/images/distance/Distance Learning_Strategies_for_Strings.pdf [27 May 2021]

Drožđek, Sara; Luštek, Anja and Rugelj, Jože (2019), "Večpredstavna učna gradiva za boljše usposabljanje učiteljev", in: Rugelj, Jože; Ferk Savec, Vesna (eds.), Inovativna didaktična uporaba informacijsko komunikacijske tehnologije $v$ študijskem procesu, pp. 11-33. Available at: https://repozitorij.uni-lj.si/Dokument.php?id=123308\&lang=slv [27 May 2021]

Flogie, Andrej and Aberšek, Boris (2019), Inovativna učna okolja - vloga IKT, Maribor: Zavod Antona Martina Slomška. Available at: https://en.calameo. $\mathrm{com} / \mathrm{read} / 0058307531$ fae8501 fad2 [15 July 2021]

Gerlič, Ivan (2006), "Konceptualno učenje in interaktivna učna gradiva", Organizacija, 39(8), pp. 472-474. Available at: https://core.ac.uk/download/ pdf/229637502.pdf [10 July 2021]

Gerlič, Ivan (2013), Informacijsko komunikacijske tehnologije v slovenskih osnovnih šolah: stanje in možnost, Ljubljana: Ministrstvo za izobraževanje, znanost in šport.

Jedrinović, Sanja; Bevčić, Mateja; Rugelj, Jože and Ferk Savec, Vesna (2019), "Aktivni pouk in uporaba IKT v procesu učenja in poučevanja", in: Rugelj, Jože; Ferk Savec, Vesna (eds.), Inovativna didaktična uporaba informacijsko komunikacijske tehnologije $v$ študijskem procesu, pp. 33-53. Available at: 
https://repozitorij.uni-lj.si/Dokument.php?id=123308\&lang=slv $\quad[20$ June 2021]

Kavčič Pucihar, Ana (2019), Učiteljeve strategije poučevanja pri individualnem inštrumentalnem pouku flavte v glasbenih šolah, Univerza v Ljubljani: Akademija za glasbo. Available at: https://repozitorij.uni-lj.si/Dokument. php?id=141696\&lang=slv [12 July 2021]

Kolman, Kristian and Rugelj, Jože (2019), "Inovativni pristop k poučevanju violine na osnovi kognitivne teorije učenja z večpredstavnostjo", in: Rotar Pance, Branka (ed.), Mostovi med formalnim in neformalnim glasbenim izobraževanjem, Glasbenopedagoški zbornik Akademije za glasbo v Ljubljani, 31, pp. 83-101.

Kranjc, Živa; Huskić, Adelisa; Kokol, Zala and Košir, Katja (2020), Učenje in poučevanje na daljavo v času zaprtja šol zaradi epidemije COVID-19: perspektiva pedagoških delavcev $v$ osnovnih in srednjih šolah v prvem mesecu izvdebe pouka na daljavo, Univerza v Mariboru: Filozofska fakulteta. Available at: https://e-knjige.ff.uni-lj.si/znanstvena-zalozba/catalog/downlo$\mathrm{ad} / 243 / 347 / 5754-1$ ?inline= 1 [20 July 2021]

Lango, Jožko (2011), Poučevanje glasbene vzgoje z uporabo informacijsko komunikacijske tehnologije, Univerza v Ljubjani: Pedagoška fakulteta. Available at: http://pefprints.pef.uni-lj.si/535/1/Pou\%C4\%8Devanje_GVZ_z_IKT_ Lango.pdf [22 July 2021]

Lifelong learning programme (2007), Key Competences for Lifelong Learning - A European Framework, Luxembourg: Office for Official Publications of the European Communities. Available at: https://www.britishcouncil.org/sites/ default/files/youth-in-action-keycomp-en.pdf [21 July 2021]

Luštek, Anja; Rugelj, Jože; Drožđek, Sara and Vogrinc, Janez (2019), "Kaj o digitalnih kompetencah študentov pedagoških študijskih programov menijo napredni uporabniki IKT med visokošolskimi učitelji Univerze v Ljubljani", in: Rugelj, Jože; Ferk Savec, Vesna (eds.), Inovativna didaktična uporaba informacijsko komunikacijske tehnologije $v$ študijskem procesu, pp. 53-71. Available at: https://repozitorij.uni-lj.si/Dokument.php?id=123308\&lang=slv [22 July 2021]

Mayer, Richard E. (2013), 'Učenje s tehnologijo", in: Dumont, Hanna; Istance, David; Benavides, Francisco (eds.), O naravi učenja: uporaba raziskav za navdih prakse, pp. 163-183. Available at: https://www.zrss.si/pdf/o-naravi-ucenja.pdf [22 July 2021]

Oblak, Breda (1997), "Ustvarjalnost v glasbeni vzgoji", in: Kuret, Primož (ed.), Glasbeno-pedagoški zbornik, 2, pp. 121-129.

Redecker, Christine (2017), European Framework of Digital Competences for Educators: DigCompEdu, Luxembourg: Publications Office of the European Union. Available at: https://publications.jrc.ec.europa.eu/repository/handle/ JRC107466 [25 July 2021]

Rossing, Jonathan; Miller, Willie M.; Cecil, Amanda K. and Stamper, Suzan E. (2012), "iLearning: The future of higher education? Student perceptions on learning with mobile tablets", Journal of the Scholarship of Teaching 
and Learning, 12 (2), pp. 1 - 26. https://www.researchgate.net/publication/285314040_iLearning_The_future_of_higher_education_Student_perceptions_on_learning_with_mobile_tablets [25 July 2021]

Rotar Pance, Branka and Bohak Adam, Tina (2019), "Vključevanje informacijskokomunikacijske tehnologije $\mathrm{v}$ didaktično usposabljanje bodočih učiteljev glasbe", in: Rugelj, Jože; Ferk Savec, Vesna (eds.), Inovativna didaktična uporaba informacijsko komunikacijske tehnologije $v$ študijskem procesu, pp. 263-281. Available at: https://repozitorij.uni-lj.si/Dokument. php?id=123308\&lang=slv [15 June 2021]

Savage, Jonathan (2007), "Reconstructing Music Education through ICT", Research in Education, (78), pp. 65-77. Available at: http://www.jsavage.org.uk/ jsorg/wp-content/uploads/2011/03/Reconstructing-music-education.pdf [25 June 2021] https://doi.org/10.7227/RIE.78.6

Šimunovič, Natalija (2020), "Poučevanje inštrumenta v času epidemije Covid-19", in: Habe, Katarina (ed.), Glasbenopedagoški zbornik Akademije za glasbo $v$ Ljubljani, 32, pp. 11-39. https://doi.org/10.26493/2712-3987.16(32)

Tomić, Ana (2003), Izbrana poglavja iz didaktike, Ljubljana: Center za pedagoško izobraževanje Filozofske fakultete.

Urbančič, Matej; Kristl, Nina and Vogrinc, Janez (2019), "Stališča študentov pedagoških študijskih programov UL do uporabe IKT v pedagoškem procesu", in: Rugelj, Jože; Ferk Savec, Vesna (eds.), Inovativna didaktična uporaba informacijsko komunikacijske tehnologije $v$ študijskem procesu, pp. 71-89. Available at: https://repozitorij.uni-lj.si/Dokument.php?id=123308\&lang=slv [5 June 2021]

Valant, Martina (2016), "Pouk v glasbeni šoli po šolski prenovi", in: Rotar Pance, Branka (ed.), Javno glasbeno šolstvo na Slovenskem - pogledi ob 200-letnici, Glasbenopedagoški zbornik Akademije za glasbo v Ljubljani, 25, pp. 217-237.

Winkler Kuret, Lučka (2006), Zdaj je nauka zlati čas, Nova Gorica: založba Educa, Melior d.o.o.

Zadnik, Katarina (2019), Nauk o glasbi v slovenski glasbeni šoli: med preteklostjo, sedanjostjo in prihodnostjo, Ljubljana: Znanstvena založba Filozofske fakultete Univerze v Ljubljani. https://doi.org/10.4312/9789610601593

Zavod za šolstvo Republike Slovenije, Sodelov@lnica.Glasba, Učna gradiva učiteljev za pouk glasbe na daljavo: marec-maj 2020. https://skupnost.sio.si/ $\mathrm{mod} /$ folder/view.php?id=332853 [20 July 2021] 


\title{
INTERAKTIVNI NASTAVNI MATERIJALI ZA PREDMETE GLAZBENA TEORIJA I SOLFEGGIO U OSNOVNIM GLAZBENIM ŠKOLAMA U SLOVENIJI
}

\author{
Katarina Zadnik
}

Opće $i$ glazbeno obrazovanje u situaciji pandemije u potpunosti je prešlo na model učenja na daljinu. Istraživanjem se željelo ustanoviti koje su didaktičke pristupe primjenjivali učitelji $i$ učenici u slovenskim glazbenim školama tijekom asinkronog učenja na daljinu. Na uzorku od 9 aktivnih učitelja $i 16$ učenika analiziran je 31 interaktivni nastavni materijal kako bi se odredili inovativni didaktički pristupi u korištenju digitalne tehnologije s ciljem ostvarenja ishoda učenja na nastavi Glazbene teorije $i$ Solfeggia. Primjenom kvalitativnih $i$ kvantitativnih metoda došlo se do rezultata koji ukazuju na nisku zastupljenost didaktičkih pristupa koji koriste digitalne tehnologije. Iako su rezultati pokazali visoku učestalost korištenja digitalne tehnologije među učenicima, istaknuta je $i$ prisutnost materijala za e-učenje te tradicionalnih nastavnih pristupa, poput onih korištenih u klasičnom tipu učioničke nastave.

Ključne riječi: asinkrono učenje na daljinu, didaktički pristupi korištenju digitalne tehnologije, materijali za e-učenje, glazbena škola, Glazbena teorija, Solfeggio 